УДК 623.445: 355.61:355.48

МЕЛЬКІН В. В.

http://orcid.org/0000-0002-9345-3396

https://doi.org/10.33577/2313-5603.33.2020.240-254

\title{
СТВОРЕННЯ І РОЗВИТОК ВІТЧИЗНЯНИХ ЗАСОБІВ ІНДИВІДУАЛЬНОГО БРОНЬОВОГО ЗАХИСТУ ВОЇНА ПІД ЧАС АНТИТЕРОРИСТИЧНОЇ ОПЕРАЦІЇ НА СХОДІ УКРАЇНИ
} (2014 - 2017 pp.)

У статті розглянуті проблеми створення та вдосконалення засобів індивідуального броньового захисту воїнів в бою в період проведення Антитерористичної операції на Сході України в 2014 - 2017 рр. При цьому основна увага приділяється створенню та вдосконаленню вітчизняних засобів захисту і, перш за все, бронежилетів та бронешоломів, а також компонентів та матеріалів, 3 яких вони виготовляються. Автор підкреслює, що за цей період у розвитку засобів індивідуального броньового захисту було досягнуто значного прогресу. Якщо на початку Антитерористичної операції вітчизняні засоби індивідуального броньового захисту за деякими характеристиками поступалися кращим світовим зразкам, то в кінці операції стали на рівні, а за деякими параметрами навіть вийшли вперед.

Ключові слова: засоби індивідуального броньового захисту, бронежилет, бронешолом, захисні матеріали, Антитерористична операція.

Постановка проблеми та ї̈ актуальність. Проблемою розробки вітчизняних засобів індивідуального броньового захисту (ЗІБЗ) в Україні займалися 3 перших років ії незалежності. Однак, на початку цього шляху створити свої надійні засоби захисту було досить складно, незважаючи на те, що в країні був багатий історичний досвід (Гуржий, 2004: 66-75; Слюсаренко, 2019: 143-144). Складні соціально-політичні, фінансово-економічні та інші умови в країні обмежували можливості виробників, воєнних вчених, практиків у вирішенні цих питань (Мелькін, 2018: 5).

Однак, Антитерористична операція (АТО), що почалася на Сході України навесні 2014 року, гостро поставила цю проблему. Воїни, які брали участь в боях, виявилися абсолютно незахищеними (без сучасних ЗІБЗ), вони йшли в бій в кращому разі в старих бронежилетах ще радянського зразка, типу 6Б5 - громіздкими, масою більше 12 кг, які сковували їх рухливість і маневреність.

Мелькін Василь Володимирович, начальник науково-організаційного відділу Центрального науково-дослідного інституту озброєння та військової техніки Збройних Сил України, м. Київ

(C) Мелькін В.В., 2020 
Але вже до весни 2015 року ситуація в районі АТО значно змінилась. До цього часу в Україні на базі вітчизняного бронежилета “Корсар М3”, розробленого ще в 2002 році науково-виробничим підприємством (НВП) “ТЕМП-3000” для українських військовослужбовців, які брали участь у миротворчих місіях в Іраку, СьєрраЛеоне та інших “гарячих точках", були розроблені і його модифікації: "Корсар М3м”, “Корсар М3с", "Корсар М3сн” та ін. (Бронежилети зовнішнього носіння). Як базовий бронежилет, так і його модифікації, забезпечували захист військовослужбовців як від осколків, так і від куль калібру 7,62 мм, відповідного типу куль четвертого рівня захисту.

Значний прогрес у розвитку ЗІБЗ в Україні стався в 2017 р. До цього часу ТОВ “НВП” ТЕМП-3000” були виготовлені і пройшли випробування нові, з кращими якостями, вітчизняні бронежилети: “Корсар МЗсм”, “Корсар МЗмк”, “Корсар МЗмп” та ін. На даний час всі підрозділи, що виконували і зараз виконують бойові завдання в районі проведення АТО і Операції Об'єднаних сил (ООС), в цілому забезпечені бронежилетами і бронешоломами.

Аналіз останніх досліджень $і$ публікащій. Створенню та розвитку засобів індивідуального броньового захисту присвячено багато науково-технічних, довідкових, історичних та інших робіт. Серед них безумовний інтерес викликають роботи: В. Григоряна (2008) “Материалы защитных структур для локального и индивидуального бронирования"; С. Попова (1986) "Полимерные волокнистые материалы”. В цих працях автори розглядають технічні аспекти розвитку броньових матеріалів, їх технічні характеристики, структуру, способи їх отримання. В статті Е. Зеленського (2001) “Армированные пластины - современные конструкционные материалы” автор розглядає способи отримання зазначених матеріалів і їх властивості, а в статтях О. Челобітченка (2018) та В. Сахна (2019) розглядається питання визначення міцності, ергономіки та ін. Але разом 3 тим в них або взагалі не показується процес створення сучасних засобів індивідуального бронезахисту, або тільки згадується про нього.

Останнім часом проблемам створення і вдосконалення сучасних ЗІБЗ присвячено ряд статей в інтернеті. Серед них: "Русские бронежилеты. бронежилет: история, классификаџия и перспективы развития”, “Доспехи современных воинов - какие бронежилеты защищают жизни бойцов”, “Военные погибают в зоне АТО 
из-за бронежилетов без брони”, “История и конщепџии создания армейских средств индивидуальной бронезащить”, “История бронежилета". Однак і в них недостатньо уваги приділено загальним проблемам вдосконалення вітчизняного бронежилета в період 2014-2017 pp.

Мета та завдання дослідження. Розкрити процес створення і розвитку вітчизняних засобів броньовий захисту, перш за все бронежилетів в період проведення АТО на Сході України в 20142017 pp.

Виклад основного матеріалу. Автор встановив, що в Україні в період проведення АТО проблему забезпечення бронежилетами воїнів, які брали участь в ній, намагалися вирішити кілька фірм, серед яких: ТОВ "НВП” ТЕМП-3000"; ТОВ "Матеріалознавство"; ТОВ “Зовнішторгбуд”; ТОВ "Укроборонекспорт"; ТОВ “ВП” Компанія “ДіСi”. Природно між ними розгорнулася гостра конкурентна боротьба за ринок збуту своєї продукції. В цій боротьбі перемогу на початку здобули два підприємства ТОВ "НВП “ТЕМП-3000” та ТОВ “ВП” Компанія “ДіСі”.

Для закупівлі їх бронежилетів, ще до початку АТО був прийнятий спеціальний Закони України від 10.04.14 №1197-VII “Про здійснення державних закупівель”. Цей Закон був опублікований у газеті "Голосі України" 19.04.2014 № 78 (Закон Украӥни “Про здійснення державних закупівель”, 2014: 8-9).

На його підставі Міністерством оборони України були визначені терміни та умови проведення торгів захисної продукції, визначено критерії, яким повинні відповідати представлені на торги бронежилети. Слід зауважити, що ці критерії були не нові. Вони були визначені в 2003 році і введені в дію Наказом Міністра оборони України від 29.12.2003 № 458 "Про прийняття на озброєння Збройних сил України спеціальних засобів та закріплення їх за службами забезпечення”.

Відповідно до цього наказу бронежилет, що поставляється для потреб Сухопутних військ Збройних Сил України, повинен був відповідати таким критеріям: балістичний пакет базового жилета повинен бути виготовлений з параарамідної тканини типу “КЕВЛАР”, бронеелементи повинні бути виготовлені з керамічних матеріалів на основі карбіду бору або карбіду кремнію з підкладкою з арамідної тканини, допускається використання сталевої або титанової пластини; балістична стійкість м'якого бронепакета - 
протиосколкова стійкість - відповідати стандарту НАТО (STANAG 2920); тверді бронеелементи грудної частини та спини виготовлені або з кераміки, або з металу та відповідати четвертому класу захисту (ДСТУ В 4103-2002); конструкція бронежилета повинна бути розроблена за чотирма основними розмірами (перший - $44-46 /$ зріст $170-176$ см, другий - 48 - 50/зріст $176-$ 182 см, третій $-52-54 /$ зріст $182-188$ см, четвертий $-56-58 / 3$ ріст 188 і вище); температурний діапазон роботи бронежилета - $50^{0}-$ $+50^{\circ} \mathrm{C}$, також в бронежилеті необхідно передбачити можливість природної вентиляції піджилетного простору, забезпечити тривалість безперервного носіння не менше однієї доби; вага без бронеелементів - не більше 3,2 кг, 3 двома металевими елементами повинна бути не більше 11,5 кг, 3 двома керамічними елементами не більше 8,5 кг, площа захисту м'якої частини - не менше 55 дм², одного бронеелемента - не менше 7,5 дм².

Після процедури торгів Міністерством оборони України було прийнято рішення брати на забезпечення Збройних Сил України бронежилет “Корсар 4”, розроблений ТОВ “НВП “ТЕМП-3000”. Однак після його натурних випробувань Центральним науководослідним інститутом озброєння та військової техніки Збройних Сил України (ЦНДІ ОВТ ЗСУ), в ньому були виявлені невідповідності висунутих до бронежилета критеріїв. Про це керівництвом ЦНДІ ОВТ ЗСУ на адресу Центрального управління речового забезпечення Тилу Збройних Сил України було спрямовано повідомлення від 25.04.2014 р. № 2/1265 (Збірник Актів натурних випробувань засобів броньового захисту, 2019: 14), в якому вказувалося, що бронежилет “Корсар 4" не відповідає тактико-технічним вимогам до бронежилетів Сухопутних військ України Збройних Сил України, зокрема площі м'якого бронепакета та забезпеченню можливості укомплектування захисним коміром для захисту шиї. Після цього питання прийняття на забезпечення Збройних Сил України бронежилета “Корсар 4” було винесене для прийняття рішення виконуючого обов'язки Міністра оборони України генералполковника М.В. Коваля. Його рішенням бронежилет "Корсар 4" був прийнятий як основний бронежилет для оснащення Високомобільних десантних військ Збройних Сил України. Через десять днів Міністерством оборони України було дано доручення Департаменту державних закупівель та постачання матеріальних ресурсів Міністерства оборони України щодо негайного придбання бронежилетів загальною кількістю 20800 комплектів, з них бронежилетів 
“Корсар М3-4” у кількості 10000 комплектів, бронежилетів “Корсар 4" - 10800 комплектів. Комісією з конкурсних торгів було затверджено зміни до Річного плану з очікуваною вартістю в 3800 грн за один комплект кожного типу, на загальну суму 76304 тис. грн.

Переговори щодо закупівлі бронежилетів за переговорною процедурою закупівлі пройшли 13.05.2014 року, на які було запрошено 5 учасників, а саме: ТОВ "НВП “ТЕМП-3000”, ТОВ “МАТЕРІАЛОЗНАВСТВО”, ТОВ “УКРОБОРОНЕКСПОРТ”, ТОВ “АММOC” та ТОВ “ВП” Компанія “ДіСі”.

За результатами цих переговорів Департаментом Державних закупівель та постачання матеріальних ресурсів Міністерства оборони України укладено договори з ТОВ "НВП “ТЕМП-3000” № 286/3/14/26, 286/3/14/27, 286/3/14/28 на постачання бронежилетів "Корсар 4" (Збірник Актів натурних випробувань засобів броньового захисту, 2019: 17). ТОВ "НВП “ТЕМП-3000” пропонувало укласти договір і на закупівлю бронежилета "Корсар М3-1-4", але він не був прийнятий, так як цей бронежилет не відповідав деяким тактико-технічним вимогам. Так, наприклад, в його комплектації був відсутній захист шиї і паху, що зменшував площу захисту м'якого пакета до 40-45 дм². Його ціна була завищена щодо первісно заявленої і становила 4200 гривень за одиницю.

Однак, в результаті подальших переговорів Департаментом Державних закупівель та постачання матеріальних ресурсів Міністерства оборони України 30 травня 2014 року було укладено відповідні договори з ТОВ ”НВП “ТЕМП-3000” № 286/3/14/29, № 286/3/14/30, № 286/3/14/31, № 286/3/14/32 на закупівлю бронежилетів “Корсар М3-1-4” зі зменшеною площею захисту гнучкого балістичного пакета з 56,0-60,0 дм² до 40,0-45,0 дм² за рахунок коміру та паху.

Цей бронежилет пройшов перевірку на балістичну стійкість в Центральному науково-дослідному інституті озброєння та військової техніки Збройних Сил України. В акті його дослідження в ЦНДІ ОВТ ЗСУ від 26 червня 2014 року № 2/1908 було відзначено, що бронежилет “Корсар М3c-1-4” (полегшений, без захисту коміру та паху) вищезазначеним тактико-технічним характеристикам не відповідав за площею захисту гнучкого балістичного пакета (Збірник Актів натурних випробувань засобів броньового захисту, 2019: 19). 
19 серпня 2014 року Міністр оборони України генераллейтенант Гелетей В.В., враховуючи позитивні результати випробувань бронежилетів, видав Наказ № 541 "Про прийняття на забезпечення Збройних сил України бронежилета “Корсар М3c-1-4", “Корсар М3-1-4”, “Корсар М3м-1-4”, “Корсар-1-4”. В Наказі кожному типу бронежилетів був привласнений код предмета постачання за класифікатором озброєння військової техніки та майна Міністерства оборони України, надане повне найменування, основні технічні та захисні характеристики, нормативну (конструкторську), експлуатаційну документацію вказаних бронежилетів. Функції служби забезпечення бронежилетами Наказом були покладені на Центральне управління речового забезпечення Збройних Сил України Тилу Збройних сил України. В додатку до Наказу Міністра оборони України № 541 за підписом тимчасово виконуючого обов'язки начальника Тилу Збройних Сил України полковника Л.Ф. Харахаліля були представлені основні технічні та захисні характеристики бронежилетів, які тоді офіційно були прийняті для оснащення підрозділів Збройних Сил України, які брали участь в АТО на Сході України.

Основні технічні та захисні характеристики бронежилетів, визначені додатком до Наказу Міністра оборони України від 19.08.2014 року № 541 наведені в табл. 1.

Таблиия 1

Основні технічні та захисні характеристики бронежилетів

\begin{tabular}{|l|c|c|c|c|}
\hline \multirow{2}{*}{$\begin{array}{c}\text { Найменування і основні захисні } \\
\text { характеристики }\end{array}$} & \multicolumn{4}{|c|}{$\begin{array}{c}\text { Тип бронежилета, кількість найменувань та } \\
\text { показники характеристик }\end{array}$} \\
\cline { 2 - 5 } & $\begin{array}{c}\text { "Корсар } \\
\text { М3с-1-4” }\end{array}$ & $\begin{array}{c}\text { "Кopсар } \\
\text { M3-1-4”" }\end{array}$ & $\begin{array}{c}\text { "Корсар } \\
\text { M3м-1-4”" }\end{array}$ & $\begin{array}{c}\text { “Корсар } \\
1-4 ”\end{array}$ \\
\hline чохол до бронежилета & 1 & 1 & 1 & 1 \\
\hline $\begin{array}{l}\text { гнучкий захисний пакет грудної } \\
\text { частини }\end{array}$ & 1 & 1 & 1 & 1 \\
\hline $\begin{array}{l}\text { гнучкі захисні пакети спинної } \\
\text { частини }\end{array}$ & 1 & 1 & 1 & 1 \\
\hline жорсткий захисний елемент & $2-4$ & $2-4$ & $2-4$ & $2-4$ \\
\hline сумка & 1 & 1 & 1 & 1 \\
\hline паспорт & 1 & 1 & 1 & 1 \\
\hline $\begin{array}{l}\text { площа захисту гнучкого баліс- } \\
\text { тичного пакета (не менш), дм }\end{array}$ & 52,0 & 38,0 & 52,0 & 30,0 \\
\hline $\begin{array}{l}\text { клас захисту гнучкого балі- } \\
\text { стичного пакета за ДСту }\end{array}$ & 1 & 1 & 1 & 1 \\
\hline $\begin{array}{l}\text { площа захисту жорстких захис- } \\
\text { них елементів (не менш), дм }\end{array}$ & 15,0 & 15,0 & 15,0 & 15,0 \\
\hline $\begin{array}{l}\text { клас захисту жорстких захи- } \\
\text { сних елементів за ДСту }\end{array}$ & 4 & 4 & 4 & 4 \\
\hline
\end{tabular}


Як видно з таблиці, всі чотири типи бронежилетів були представлені по четвертому класу захисту. Всі вони відносилися до бронежилетів зовнішньо типу носіння, напівжорсткі, з базовою захисною структурою на основі спеціальної тканини, з додатковими жорсткими захисними елементами, призначені для індивідуального захисту тіла військовослужбовця від ураження кулями вогнепальної зброї і осколками. Крім того, бронежилети “Корсар М3м-1-4” і “Корсар М3c-1-4” були оснащені системою кріплення спорядження типу "MOLLE".

Таким чином, проблема забезпечення військовослужбовців Збройних Сил України, які брали участь в АТО, почала вирішуватися. Однак до іï вирішення було ще занадто далеко. Справа в тому, що за якісними показниками вітчизняні бронежилети часто не відповідали вимогам, які до них були висунуті.

Крім того, три зразки бронежилетів: “Корсар М3м-1-4”, “Корсар М3c-1-4", “Корсар 1-4”, представлених в додатку до Наказу Міністра оборони України від 19 серпня 2014 року № 541 мали невелику площу захисту гнучкого балістичного пакета. Так, у “Корсар М3м-1-4” і “Корсар М3c-1-4” вона була 38,0 дм², а у “Корсар 1-4” всього 30 дм², що не відповідало технічним умовам ТУ У 18.2-31778043.046-2003 і ТУ У 18.2-31778043-008:2008.

Щоправда, за площею захисту жорстких захисних елементів всі представлені бронежилети в додатку до Наказу Міністерства оборони України від 19.08.2014 року №541 відповідали вимогам технічних умов. Крім того, кожен бронежилет комплектувався $2-4$ жорсткими захисними елементами. Причому два з них розмірами 250x300 мм (7,5 дм²) забезпечували пред'явлену площу захисту

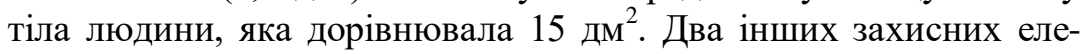
менти призначалися для захисту боків бійця. Це було позитивним явищем для всіх чотирьох типів бронежилетів, прийнятих на оснащення підрозділів Збройних сил України в серпні 2014 року. Що стосується прийняття на забезпечення в той час бронежилетів 3 деякими недоліками, зазначеними вище, слід зауважити наступне. В умовах розпочатої АТО, бійці, які брали участь в ній, практично опинилися без ЗІБЗ. Приймали тоді на забезпечення ті засоби захисту, які були в наявності. I, на наш погляд, тоді це було правильно і необхідно.

Зауважимо, що до початку АТО на Сході України не було цілісної системи контролю засобів індивідуального броньового 
захисту військовослужбовців. Захисні та інші властивості бронежилетів і бронешоломів перевірялися епізодично, коли було потрібно, наприклад, оснастити ними миротворчий контингент, який відправлявся в якусь “гарячу точку”.

Вона була створена в умовах АТО, яка тільки почалась. В цей час в Україні почали функціонувати декілька лабораторій, які були акредитовані в Національному агентстві з акредитації України, отримали Свідоцтва 3 акредитації щодо відповідності вимогам ДСТУ ISO/IEC 17025:2006 року на міждержавному рівні та мають право проведення випробувань ЗІБЗ. До них відносяться: наукововипробувальна лабораторія НУОУ імені І. Черняховського; лабораторія сертифікації ручної вогнепальної зброї і спецзасобів самозахисту Державного науково-дослідного інституту МВС України; відділення балістичного стрілецького озброєння та боєприпасів відділу технічного контролю за якістю боєприпасів 303 бази зберігання ракет і боєприпасів.

Основним їх призначенням $є$ проведення наукових досліджень за напрямами розвитку зброї, боєприпасів і спеціальних засобів броньового захисту, а також можливість підвищення захищеності індивідуальних і колективних засобів захисту, виконання випробувань на замовлення установ Міністерства оборони України та інших Міністерств, а також приватних організацій. Крім того, лабораторії проводять випробування спеціальних засобів індивідуального та колективного бронезахисту, елементів основного і додаткового бронювання легкоброньованої техніки, а також нових і модернізованих зразків вогнепальної зброї і набоїв до неї.

Що стосується науково-дослідної лабораторії університету імені I. Черняховского слід відзначити іiі велику роботу в області виявлення невідповідності заявленої та реальної якості ЗІБЗ, порушення їх конструкції, геометричних розмірів, складу матеріалу, умов, що забезпечують гарантований протикульний захист при мінімальних геометричних розмірах і масі, а також вартості.

За час проведення АТО на Сході України науково-дослідна лабораторія університету імені І. Черняховского провела близько 320 випробувань різних ЗІБЗ. При цьому в 132 випадках знайдено завищення захисних властивостей. Результати випробувань ЗІБЗ наведені в табл. 2.

Як видно $з$ таблиці, кількість випробовуваних засобів бронезахисту, які не підтвердили свій клас за цей період часу, досягла $43 \%$. 
Причому в перший рік проведення АТО цей показник склав майже $53 \%$, в 2015 році опустився до 50\%, а до кінця АТО він склав всього $34 \%$.

Таблиияя 2

Результати випробувань 3 ІБ3

\begin{tabular}{|l|l|c|c|c|c|c|}
\hline \multirow{2}{*}{$\begin{array}{l}\text { № } \\
\text { 3/п }\end{array}$} & \multirow{2}{*}{$\begin{array}{c}\text { Проведено } \\
\text { випробувань }\end{array}$} & \multicolumn{5}{|c|}{ Роки проведення випробувань } \\
\cline { 3 - 7 } 1 & $\begin{array}{l}\text { Всього } \\
\text { випробувань }\end{array}$ & 38 & 93 & 64 & 125 & 320 \\
\hline 2 & $\begin{array}{l}\text { Виявлено } \\
\text { невідповідності, } \\
\text { всього /\% }\end{array}$ & $20 / 53$ & $47 / 50$ & $23 / 36$ & $42 / 34$ & $132 / 432$ \\
\hline
\end{tabular}

Таблиця складена за матеріалами: (Челобітченко, 2018: 54), (Сахно, 2019: 57).

Висока вимогливість особового складу лабораторії до пред'явлених на випробування ЗІБЗ дала змогу уникнути постачання неякісної продукції в Збройні сили України, інші військові формування i правоохоронні органи, а виробникам та експертам своєчасно внести відповідні зміни до технологічних процесів виготовлення таких виробів, або взагалі відмовитися від їх постачання, що суттєво вплинуло на збереження особового складу підрозділів, що беруть участь в АТО на Сході України.

З 2014 року науково-дослідна лабораторія університету імені I. Черняховского в галузі випробування на балістичну стійкість ЗІБЗ військовослужбовців почала взаємодіяти з Центральним науководослідним інститутом озброєння та військової техніки Збройних Сил України (ЦНДІ ОВТ ЗСУ), що очолював генерал-майор І.Б. Чепков. На цей Інститут з початком військових дій на Сході України навесні 2014 року було покладено завдання Міністерством оборони України проводити випробування ЗІБЗ на предмет їхньої балістичної стійкості. Інститут не мав права сертифікації випробуваних зразків, але він видавав замовникам акти натурних випробувань на перевірену продукцію. Свої випробування ЗІБЗ ЦНДІ ОВТ ЗСУ проводив на полігонах і центрах Міністерства оборони, у тому числі і військової частини А3723. Акти інституту були офіційним документом, який використовувався для прийняття подальшого рішення щодо використання представлених на випробування ЗІБЗ під заявленим класом і заявленими їх характеристиками. 
Взаємодія ЦНДІ ОВТ ЗСУ з зацікавленими організаціями у перевірки своїх засобів захисту здійснювалася наступним чином. Зацікавлена організація, зверталася письмового до Міністерства оборони України (Міністра оборони України, начальника Тилу Збройних сил України). Вони відповідними дорученнями зверталися до ЦНДІ ОВТ ЗСУ щодо проведення випробування наданих ЗІБЗ. В інституті створювалася комісія (в ході АТО вона була, як правило, постійно діюча), яка організовувала і проводила ці випробування. Комісію, як правило, очолював заступник начальника інституту.

За результатами проведення випробувань комісії складався Акт натурних випробувань, який підписувався членами комісії і затверджувався начальником інституту, завірявся печаткою інституту. Один примірник Акта направлявся до Міністерства оборони України, другий - до зацікавленої організації, третій залишався на зберіганні в інституті. Всі екземпляри актів випробувань 3 ІБЗ нині перебувають в інституті і зберігаються за окремими інвентарними № А-679 і № А-679/1.

У кожному акті ЦНДІ ОВТ ЗСУ обов'язково вказувалося: за чиїм рішенням проводять натурні випробування зразків; склад комісії; тип, кількість і склад зразків із загальною характеристикою кожного з них; мету випробування, результати випробувань і висновок комісії. Так, наприклад, при підготовці проекту наказу Міністра оборони України від 19 серпня 2014 року № 541 випробування зразків бронежилетів "Корсар М3-1-4" і “Корсар-1-4" ТОВ “НВП“ТЕМП-3000” проводилося відповідно до доручення Адміністрації Президента України від 03.07.2014 року № 41-01/1997 (Збірник Актів натурних випробувань засобів броньового захисту, 2019: 12). Натурні випробування проходили на базі військової частини А3723. Після надання ЦНДІ ОВТ ЗСУ негативного відгуку на досліджувані зразки повторні випробування зразків зазначених типів бронежилетів проводилися на підставі рішення заступника Міністра оборони України від 09.07.2014 року на базі 33 полігону 169 навчального центру (с. Десна).

i “Корсар-1-4" на полігоні навчального центру Повторні випробування зразків бронежилетів “Корсар М3-1-4” проводились у присутності представника Адміністрації Президента України, Департаменту Державних закупівель та постачання матеріальних ресурсів Міністерства оборони України, Центрального управління 
речового забезпечення Збройних Сил України Тилу Збройних Сил України, 1363 Головного військового представництва Міністерства України і ТОВ “НВП“ТЕМП-3000”.

Розширення кола учасників у випробувальному процесі зразків бронежилетів свідчить, про принциповий підхід ЦНДІ ОВТ ЗСУ до оцінки якості бронежилетів, які надходили в зону проведення АТО. ТОВ “НВП“ТЕМП-3000” прислухалися до зауважень, зазначених в Акті інституту від 04.07.2014, і представило нові зразки для повторного випробування вже з урахуванням цих зауважень. В висновках комісії після повторної перевірки було відзначено тільки деякі невідповідності заявлених зразків бронежилетів по четвертому класу захисту, в частині, що стосується обстрілу їх кулями ЛПС 7.621989 року виготовлення.

Тільки спочатку АТО і до кінця 2014 року інститутом було проведено понад 40 натурних випробувань бронежилетів і захисних елементів до них (Збірник Актів натурних випробувань засобів броньового захисту, 2019: 1-10). Випробування проводилися в полігонних умовах, із застосуванням патронів визначених калібрів та типів кулі. Крім ТОВ “НВП“ТЕМП-3000”, свою продукцію для випробування представляли і інші вітчизняні підприємства, наприклад, ТОВ “Весь світ бронедверей”, ТОВ ІНВП “УКРТЕХНАНО”, ПП “Свромарт”, ТОВ “Білоцерківський механічний завод” та ін.

В цілому, як показує аналіз актів за 2014 рік, більше 50\% випробовуваних вітчизняних матеріалів і захисних засобів не відповідали заявленим вимогам. Були випадки надання на випробування абсолютно непридатних до використання в ЗІБЗ захисних матеріалів. Так, наприклад, в червні 2014 року ТОВ ІНВП "УКРТЕХНАНО" представило для випробування 10 зразків захисних матеріалів для бронежилета власного виробництва. Натурні випробування з оцінки балістичної стійкості всіх дослідних зразків матеріалів, проведених 13.06.2014 на базі полігону військової частини А0665, випробування не витримали (Збірник Актів натурних випробувань засобів броньового захисту, 2019: 45). Після чого ТОВ ІНВП "УКРТЕХНАНО” свою продукцію на випробування в інститут не надавало.

На наш погляд, один з найбільш якісних засобів захисту, виконаний з балістичних матеріалів, протягом усього часу проведення АТО представило ТОВ “НВП“ТЕМП-3000”. Кращім бронежилетом цієї фірми був бронежилет “Корсар М3c-1-4”. Він відповідав усім вимогам відповідних документів. Бронежилет виготовлявся 
iз сучасних балістичних матеріалів параарамідної тканини, виготовленої з нитки Teijin Twaron, представленою транснаціональною компанією Японії, Німеччини, Нідерландів і бронеметалу фірми SSAB (Швеція). При цьому матеріали фірми Teijin Twaron i SSAB квотовані, і підприємство ТОВ “НВП“ТЕМП-3000” отримує їх для оборонних потреб Збройних сил України десятки років поспіль, а бронеметал - з 2010 року. Ці матеріали підтвердили свої захисні властивості через 15 років експлуатації. При цьому можна не змішувати клас захисту бронежилета, і суттєво зберегти кошти державного бюджету.

В період проведення АТО ТОВ “НВП“ТЕМП-3000” виготовляло й інші бронежилети типу “Корсар" - починаючи з кінця 2016 року вони пройшли якісну модернізацію і наприкінці АТО стали представляти зовсім нові вітчизняні бронежилети. Кращі з них, за відгуками учасників АТО, є: “Корсар МЗсм”, “Корсар МЗмк”. Обидва вони є модульними і забезпечують захист по 2 - 6 класам за ДСТУ В 4103-2002 та NIJ 0101.06 (Бронежилети зовнішнього носіння).

Висновки. Отже, в період проведення АТО на Сході України було досягнуто значного прогресу в області створення і вдосконалення сучасних засобів індивідуального броньового захисту військовослужбовців. Однак не вдалася спроба створити універсальний бронежилет, придатний “на всі випадки життя”, зручний в експлуатації і який забезпечує одночасно захист від комплексу засобів ураження: осколків, куль малого і великого калібру, а також інших уражаючих факторів. Більш перспективними виявилися “вузькоспеціалізовані” бронежилети, призначені для вирішення бойових завдань в конкретних умовах обстановки, 3 диференційованим рівнем захисту по зонах, площі захисту і маси. Перспективними виявилися бронежилети з різними варіантами комплектації в залежності від їх призначення. Таким бронежилетом, наприклад, є бронежилет “Корсар МЗмк”, який може застосовуватися в 5 комплектаціях (Бронежилети зовнішнього носіння).

Досвід застосування бронежилетів в зоні проведення АТО дозволив підтвердити найбільш ефективні вимоги до них. Вони зводяться до наступного: бронежилет повинен виготовлятися 3 новітніх матеріалів; конструкція бронежилета має виконуватися 3 використанням модульного принципу, при якому зміна необхідного рівня захисту досягається простою зміною бронеелементів; бронежилет повинен володіти хорошими ергономічними і експлуатаційними якостями, не повинен знижувати бойові можливості 
бійця (стріляти, пересуватися, виконувати інші дії) і повинен об'єднуватися з іншими елементами екіпірування бійця; бронежилет повинен забезпечувати необхідний рівень захисту.

\section{Використані посилання}

Гуржий О.І., Лега А.Ю. та Макаров В.Д. (2004). Узагальнення досвіду проведення миротворчих операциї в другій половині $X X \mathrm{~cm}$., Видавництво Інституту історії України НАНУ, Київ, 94 с.

Григорян В.А., Кобилкін І.Ф., Марінін В.М., Чистяков Е.М. (2008). Материалы защитных структур для локального и индивидуального бронирования, Видавництво “РадиоСофт”, Москва, 416 с.

Зеленський Є.С., Куперман О.Н., Горбаткіна Ю.А., Іванова-Мумжиєва В.Г., Берлін О.О. (2001). “Армированные пластики - современные конструкционные материалы”, Журнал російського хімічного товариства імені Д.І. Менделєєва, т. XLV. № 2, C. 89.

Мелькін В.В. (2018). Засоби індивідуального броньованого захисту: історія сучасності, Видавництво “ЦП“Компринт”, Київ, 54 с.

Попков С.П. (1986). Полимерные волокнистые материалы, Видавництво "Химия”, Москва, 224 с.

Сахно В.П. (2019). “Контроль якості - запорука високої ефективності застосування озброєння та військової техніки”, Наука і оборона, № 1, С. 54-59.

Слюсаренко А.В. (2019). Світовий досвід розбудови та застосування сухопутного компоненту сил спещіальних операчій (друга половина XX початок XXI cm.), Львів, Національна академія сухопутних військ, 420 с.

Челобітченко О.О., Алексеенко О.В., Курбан В.А., Седов С.Г. (2018). "Балістичні випробування засобів колективного й індивідуального захисту завершення дослідницької стадії інноваційних проектів з їх створення”, Наука $i$ оборона, № 1, С. 49-55.

Бронежилети зовнішнього носіння [online] Доступно https://temp3000.com/ product-category/bronezhileti-zovnishnogo-nosinya/ [Дата звернення 20 січня 2020 p.]

Русские бронежилеты. бронежслет: история, классификаиия и перспективы развития (2019) [online] Доступно https://msknorka.ru/raznoe/russkie-bronezhiletybronezhilet-istoriya-klassifikaciya-i.html [Дата звернення 10 січня 2020 p.]

Доспехи современных воинов - какие бронежилеты защищают жизни бойцов ATO (2017) [online] Доступно https://sprotyv.info/news/dospehi-sovremennyh-voinovkakie-bronezhilety-zashhishhajut-zhizni-bojcov-ato [Дата звернення 10 січня 2020 p.]

Военные погибают в зоне АТО из-за бронежилетов без брони (2017) [online] Доступно www.litsa.com.ua/show/a/17910 [Дата звернення 10 січня 2020 p.]

История и кониепии создания армейских средств индивидуальной бронезащиты (2013) [online] Доступно www.i-mash.ru/materials/opinions/39489-istorija- ikoncepcii-sozdanija-armejjskikh.html [Дата звернення 12 січня 2020 p.]

История бронежсилета (38 фото) (2011) [online] Доступно http://nevsedoma. com.ua/index.php?newsid=104409 [Дата звернення 10 січня 2020 p.]

Закони України “Про здійснення державних закупівель” (2014), Голос України, № 78 (5828), С. 8-9.

Збірник Актів натурних випробувань засобів броньового захисту (2019), Інв. № А-679, Фонд ЦНДІ ОВТ ЗСУ, 285 с. 


\section{References}

Gurzhi O.I., Lega A.Y. and Makarov M.D. (2004) Generalization of the experience of conducting peacekeeping operations in the second half of the twentieth century, Publishers of the Institute of History of Ukraine of NASU, Kyiv, 94 p.

Grigoryan V.A., Kobylkin I.F., Marinin V.M., Chistyakov E.M. (2008) Materials of Security Structures for Local and Individual armor, RadioSoft Publishing House, Moscow, $416 \mathrm{p}$.

Zelensky E.S., Kuperman O.N., Gorbatkina Y.A., Ivanova-Mumzhieva V.G., Berlin O.O. (2001) "Armoured plastics - modern structural materials", Journal of the Russian Chemical Society named D.I. Mendeleev, XLV. №2, 89 p.

Melkin V.V. (2018) Means of individual armor protection: history of the present, Publisher "CP" Komprynt ", Kyiv, 54 p.

Popkov S.P. (1986) Polymeric Fibrous Materials, Publishing House "Chemistry", Moscow, 224 p.

Sakhno V.P. (2019) "Quality control is the key to high efficiency in the use of weapons and military equipment", Science and Defense, No. 1, 54-59 p.

Slyusarenko A.V. (2019) World experience of development and use of the ground component of special operations forces (second half of XX - beginning of XXI centuries), Lviv, National Academy of Land Forces, 420 p.

Chelobitchenko O.O., Alekseenko O.V., Kurban V.A., Sedov S.G. (2018) "Ballistic Tests for Collective and Individual Protection - Completing the Research Stage of Innovative Projects for their Creation", Science and Defense, No. 1, 49-55 p.

Exterior Wearing Body Armor [online] Available https://temp3000.com/productcategory/bronezhileti-zovnishnogo-nosinya/ [Accessed January 20, 2020]

Russian body armor: history, classification and development prospects (2019) [online] Available from https://msknorka.ru/raznoe/russkie-bronezhilety-bronezhiletistoriya-klassifikaciya-i.html [Accessed January 10, 2020]

Armor of modern warriors - what body armor protect the lives of ATO fighters (2017) [online] Available https://sprotyv.info/news/dospehi-sovremennyh-voinovkakie-bronezhilety-zashhishhajut-zhizni-bojcov-ato [Accessed January 10, 2020]

Military dies in ATO zone due to bulletproof vests without armor (2017) [online] Available from www.litsa.com.ua/show/a/17910 [Accessed January 10, 2020]

History and Concepts of Creation of Army Personal Protective Equipment (2013) [online] Available from www.i-mash.ru/materials/opinions/39489-istorija-ikoncepcii-sozdanija-armejjskikh.html [Accessed 12 January 2020]

Body armor history (38 photos) (2011) [online] Available from http:// nevsedoma. com.ua/index.php?newsid=104409 [Accessed January 10, 2020]

Laws of Ukraine "On Public Procurement" (2014), Voice of Ukraine, No. 78 (5828), pp. 8-9.

Collection of Acts of field tests of armor protection (2019), Inv. № A-679, Fund of the Central Research Institute of the Armed Forces of Ukraine, $285 \mathrm{p}$. 


\section{Melkin V.}

\section{CREATION AND DEVELOPMENT OF DOMESTIC MEANS OF INDIVIDUAL ARMOR PROTECTION OF A WARRIOR DURING THE ANTI-TERRORIST OPERATION IN THE EAST OF UKRAINE (2014 - 2017)}

The author of the article considers the problems of creation and improvement of the means of individual armor protection of soldiers in combat during the conduct of the anti-terrorist operation in the East of Ukraine in 2014 - 2017. At the same time, the main attention is paid to the creation and improvement of the main element of armor protection of a serviceman - a bulletproof vest. At the same time, it draws attention to the creation of the main components and materials of which body armor is made.

While revealing this process in complex, the author pay attention to the difficult situation in Ukraine, especially at the beginning of the anti-terrorist operation. The fact that the process of creation and improvement of the domestic bulletproof vest in 2014 - 2017 noted a fierce competitive struggle between manufacturers for the market of their products. TEMP-3000 LLC won this fight.

The author draws attention to the fact that in the first year of conducting an antiterrorist operation to provide military personnel of the Ukrainian Armed Forces, who participated in it, often received bulletproof vests with low protective properties. Only a principled approach to the assessment of their quality by the control laboratories of the I. Chernyakhovsky National University and the Central Research Institute of Arms and Military Equipment of the Armed Forces of Ukraine did not allow to accept them into service. Pointing to this, the author, however, confirms that such facts occurred, mainly, in the first year of conducting an anti-terrorist operation in the east of Ukraine under conditions of acute shortage in these funds.

In specific examples, the author shows that significant progress has been made in the development of PPE during the anti-terrorist operation. Comparing the samples of body armor during the beginning and end of the anti-terrorist operation, the author emphasizes that in many ergonomic, operational and protective characteristics they were not inferior to the world standards, and in some respects exceeded them.

Analyzing the process of creating individual armor protection in the period of ATO in 2014 - 2017, the author concludes that the most promising is "highly specialized" bulletproof vests, designed to solve combat tasks in specific conditions, with different levels of protection by zones, area and mass, with different options.

Keywords: personal armor protection, bulletproof vest, bulletproof helmet, protective materials, anti-terrorist operation. 